\title{
NOWE PRZEPISY DOTYCZĄCE FAKTUR KORYGUJĄCYCH IN MINUS - UPROSZCZENIE ROZLICZANIA VAT DLA PODATNIKÓW?
}

Streszczenie. Główną tezą artykułu jest wskazanie, że wprowadzone z dniem 1 stycznia $2021 \mathrm{r}$. zmiany w przepisach o podatku od towarów i usług w zakresie obniżenia podstawy opodatkowania i wystawiania faktur korygujących in minus, wbrew przyjętym założeniom nie prowadzą do uproszczenia rozliczania podatku od towarów i usług - zwłaszcza po stronie nabywcy towarów i usług.

Nieprecyzyjność niektórych przepisów może prowadzić do zaburzenia pewności prawa i jego spójnej wykładni. Nowe rozwiązania mogą też prowadzić do zaburzenia symetryczności obciążenia podatkiem obu stron transakcji - termin dokonania korekty podstawy opodatkowania przez sprzedawcę nie jest skorelowany z obowiązkiem korekty podatku naliczonego przez nabywcę.

Słowa kluczowe: podatek od towarów i usług, faktura VAT, faktura korygująca in minus, odliczenie podatku

* Doradca podatkowy, ekspert Instytutu Odpowiedzialnych Finansów, ekspert Zespołu Doradców Komisji Zdrowia Senatu Rzeczypospolitej Polskiej X kadencji, of counsel w Kancelarii Prawniczej Stolarek i Wspólnicy, e-mail: hanna.majszczyk@wp.pl 
Faktura VAT to w systemie podatku od towarów i usług (dalej: podatek VAT) dokument o szczególnym znaczeniu zarówno dla wykonującego czynności podlegające opodatkowaniu tym podatkiem (dalej: sprzedawca), jak i ich odbiorcy (dalej: nabywca). W pierwszym przypadku wystawienie faktury jest obowiązkiem podatnika - dokumentuje jego działania podlegające opodatkowaniu podatkiem VAT. W drugim przypadku dla nabywcy jest, co do zasady, dokumentem, którego otrzymanie warunkuje skorzystanie z podstawowego prawa podatnika VAT, jakim jest prawo do pomniejszenia podatku należnego o podatek naliczony przy nabyciu przez niego towarów i usług. Faktura ma fundamentalne znaczenie dla zachowania zasady neutralności podatku VAT. Dotyczy to również faktur korygujących.

Z początkiem $2021 \mathrm{r}$. weszły w życie istotne zmiany w zakresie wystawiania przez sprzedawcę faktur korygujących. Są one elementem zmian wprowadzonych $\mathrm{w}$ ustawie o podatku od towarów i usług ${ }^{1} \mathrm{w}$ ramach tzw. pakietu Slim VAT ${ }^{2}$. Szczególnie istotne dla podatników zmiany dotyczą faktur korygujących związanych z obniżeniem podstawy opodatkowania podatkiem VAT lub podatku należnego. Motywem przewodnim dla wprowadzenia tych zmian - jak wynika z uzasadnienia ustawy - było uproszczenie zasad rozliczania podatku VAT przez podatników.

Czy nowe rozwiązania spełniają te założenia?

Nowe regulacje zdejmują wprawdzie z podatnika dokonującego korekty (obniżenia podstawy opodatkowania lub kwoty podatku należnego) obowiązek posiadania potwierdzenia otrzymania faktury korygującej przez nabywcę, ale w zamian wprowadzają inne warunki i procedury dla dokonania korekty.

Zmieniły się również zasady dotyczące obowiązku korekty podatku naliczonego przez nabywcę w związku z obniżeniem podstawy opodatkowania lub kwoty podatku należnego. Nastąpiło całkowite „oderwanie” tego obowiązku od momentu, w którym nabywca otrzyma fakturę korygującą.

1 Ustawa z dnia 11 marca 2004 r. o podatku od towarów i usług (tekst jedn. Dz.U. z 2020 r., poz. 106 ze zm.), dalej: ustawa VAT.

2 Pakiet został wprowadzony Ustawą z dnia 27 listopada 2020 r. o zmianie ustawy o podatku od towarów i usług oraz niektórych innych ustaw (Dz.U. z 2020 r., poz. 2419), dalej: ustawa zmieniająca. 
Przepis art. 29a ust. 10 ustawy VAT wskazuje, że podstawę opodatkowania obniża się o:

1) kwoty udzielonych po dokonaniu sprzedaży opustów i obniżek cen;

2) wartość zwróconych towarów i opakowań, z zastrzeżeniem pewnych wyjątków określonych ustawą;

3) zwróconą nabywcy całość lub część zapłaty otrzymaną przed dokonaniem sprzedaży, jeżeli do niej nie doszło;

4) wartość zwróconych kwot dotacji, subwencji i innych dopłat o podobnym charakterze.

Uregulowania powyższe obowiązywały też do końca 2020 r. Zmianie uległy przepisy określające, kiedy, w związku z zaistnieniem powyższych okoliczności, następuje obniżenie podstawy opodatkowania i kwoty podatku należnego.

Obecnie, jak wynika $\mathrm{z}$ art. 29a ust. 13 ustawy VAT, w przypadkach, o których mowa wyżej, podatnik obniża podstawę opodatkowania podatkiem VAT (w konsekwencji podatek należny) lub podatek należny niezależnie od potwierdzenia przez nabywcę otrzymania faktury korygującej (jak wynikało to z przepisów obowiązujących do końca 2020 r. ${ }^{3}$ ). Obniżenia tego podatnik-sprzedawca dokonuje już w rozliczeniu za okres rozliczeniowy, w którym wystawił fakturę korygującą. Może jednak tego dokonać pod pewnymi warunkami:

1) z posiadanej przez podatnika dokumentacji musi wynikać, że uzgodnił on $\mathrm{z}$ nabywcą towarów lub usług warunki obniżenia podstawy opodatkowania dla dostawy tych towarów lub usług określone w fakturze korygującej oraz że warunki te zostały spełnione;

2) faktura korygująca jest zgodna z posiadaną dokumentacją, co oznacza, że podatnik powinien posiadać dokumenty potwierdzające ziszczenie się warunku dla dokonania korekty.

Wystawienie faktury korygującej in minus, zmniejszającej podstawę opodatkowania podatkiem VAT lub kwotę podatku należnego, wymaga zatem wystąpienia kilku przesłanek ${ }^{4}$ :

${ }^{3}$ W ustawie zmieniającej przewidziano i wprowadzono również przepisy przejściowe, które umożliwiają podatnikom, przy spełnieniu pewnych warunków, stosowanie przepisów obowiązujących przed $2021 \mathrm{r}$.

${ }_{4}$ Zasady dotyczące korekty podstawy opodatkowania stosuje się odpowiednio w przypadku stwierdzenia pomyłki podatku na fakturze i wystawienia faktury korygującej do faktury, w której wykazano kwotę podatku wyższą niż należna (art. 29a ust. 14 ustawy VAT). 
- uzgodnienia pomiędzy stronami transakcji okoliczności, warunków dokonania korekty in minus;

- faktycznego ziszczenia się tych okoliczności (warunków);

- posiadania przez podatnika stosownej dokumentacji, która potwierdza zarówno samo uzgodnienie, jak i faktyczne wystąpienie okoliczności - ziszczenie się warunków uzasadniających dokonanie korekty in minus ${ }^{5}$;

- wystawienia faktury korygującej zgodnej z posiadaną dokumentacją; w przypadku gdy w okresie rozliczeniowym, w którym została wystawiona faktura korygująca, podatnik nie posiada stosownej dokumentacji, obniżenia podstawy opodatkowania dokonuje za okres, w którym dokumentację tę uzyskał (art. 29a ust. 13 ustawy VAT).

Obniżenie podstawy opodatkowania i kwoty podatku nie jest już więc zależne od działania nabywcy (potwierdzenia otrzymania przez niego korekty), lecz od działania samego podatnika (sprzedawcy/dostawcy). Nie oznacza to jednak, że dokonanie takiej korekty jest łatwiejsze. W miejsce warunku otrzymania potwierdzenia odbioru faktury korygującej przez nabywcę wprowadzone zostały inne warunki i procedury, których spełnienie upoważnia do dokonania korekty: uzgodnienie z nabywcą okoliczności dla obniżenia podstawy opodatkowania, ziszczenie się warunków dokonania korekty, obowiązek gromadzenia formalnej dokumentacji potwierdzającej spełnienie warunków do obniżenia podstawy opodatkowania.

\section{UZGODNIENIE}

Nowe regulacje nie precyzują, jak ma wyglądać uzgodnienie pomiędzy sprzedawcą i nabywcą dotyczące warunków obniżenia podstawy opodatkowania. Z przepisów wynika, że obniżenie podstawy opodatkowania następuje, gdy sprzedawca m.in. uzgodnił z nabywcą (usługobiorcą) warunki obniżenia podstawy opodatkowania. Uzgodnienie powinno zatem zawierać warunki, kryteria, przesłanki czy okoliczności do obniżenia kwoty należnej (wynagrodzenia) wynikającej z pierwotnie wystawionej faktury.

${ }^{5}$ Warunek posiadania takiej dokumentacji nie dotyczy eksportu towarów, wewnątrzwspólnotowej dostawy towarów, dostawy towarów oraz świadczenia usług, dla których miejsce opodatkowania znajduje się poza granicami kraju, a także sprzedaży energii elektrycznej, gazu czy usług telekomunikacyjnych. 
W przepisach nie jest też wskazana forma uzgodnienia - pisemna bądź ustna. Skoro jednak z posiadanej przez sprzedawcę dokumentacji ma wynikać, że takie uzgodnienie zostało dokonane, wydaje się, że powinno zostać zawarte w formie pisemnej, np. w umowie lub innym dokumencie (dopuszczalne jest tu również uzgodnienie w formie elektronicznej). W innym przypadku, tj. przy uzgodnieniu ustnym, i tak wymagane byłoby tworzenie przez sprzedawcę specjalnej dokumentacji potwierdzającej dokonanie takiego uzgodnienia i nie wiadomo, jak wówczas taka dokumentacja miałaby wyglądać. Na możliwość dokonania także ustnych uzgodnień wskazują Objaśnienia podatkowe dotyczące Slim VAT 6 . W takim przypadku za najistotniejsze uznaje się zapewnienie odpowiedniej dokumentacji potwierdzającej ustne uzgodnienia. Jednocześnie wskazuje się, że sama notatka z przeprowadzonej rozmowy nie będzie wystarczającym dowodem dokonania uzgodnienia. Rozmowa musi być zapisana na nośniku, co może stanowić poważne utrudnienie. Przy takim podejściu ustne uzgodnienia przestają być już dla wielu podatników atrakcyjne.

\section{ZAISTNIENIE OKOLICZNOŚCI DO DOKONANIA KOREKTY}

Warunkiem dokonania korekty in minus jest nie tylko dokonanie stosownego uzgodnienia pomiędzy stronami transakcji co do okoliczności (warunków) dokonania korekty, ale także faktyczne wystąpienie tych okoliczności (spełnienie warunków). Co do zasady nie jest to wszakże nowy obowiązek. Również przed zmianą przepisów dokonanie korekty faktury in minus musiało się przecież wiązać ze ziszczeniem się okoliczności czy też warunków, które dawałyby podstawę dokonania tej korekty - nawet jeżeli nie były objęte formalnym uzgodnieniem. W nowych rozwiązaniach przewiduje się jednak dodatkowo obowiązek posiadania przez podatnika-sprzedawcę dokumentacji potwierdzającej dokonanie uzgodnienia $\mathrm{z}$ nabywcą co do okoliczności (warunków) korekty in minus.

${ }^{6}$ Objaśnienia podatkowe z dnia 23 kwietnia 2021 r. w zakresie pakietu rozwiązań „Slim VAT” oraz wybranych rozwiązań doprecyzowujących niektóre konstrukcje VAT wprowadzonych Ustawą z dnia 27 listopada 2020 r. o zmianie ustawy o podatku od towarów i usług oraz niektórych innych ustaw (Dz.U. z 2020 r., poz. 2419). 
Sprzedawca powinien posiadać dokumentację, która potwierdza dokonane z nabywcą uzgodnienia co do okoliczności obniżenia podstawy opodatkowania, a także dokumentację, z której będzie wynikało, że te okoliczności faktycznie wystąpiły. Są to nowe obowiązki dla sprzedawcy, nowe wymagania księgowe.

Obowiązujące przepisy nie wskazują, jak ma wyglądać taka dokumentacja. W przypadku samego uzgodnienia będzie to umowa lub inny dokument. Natomiast dokumentacja potwierdzająca spełnienie warunków czy też zaistnienie okoliczności uzasadniających pomniejszenie podstawy opodatkowania będzie zależeć od treści uzgodnienia i wskazanych w nim okoliczności czy warunków do pomniejszenia podstawy opodatkowania. Dokumentacja ta może być zatem różna, adekwatna do wskazanych w uzgodnieniu okoliczności lub warunków.

\section{WYSTAWIENIE FAKTURY KORYGUJĄCEJ}

Nowe przepisy mogą budzić pewne wątpliwości odnośnie do momentu, w którym podatnik powinien wystawić fakturę korygującą in minus.

Jak wynika z przepisu art. 29a ust. 13 ustawy VAT, obniżenia podstawy opodatkowania dokonuje się z chwilą wystawienia faktury korygującej, która powinna być m.in. zgodna z posiadaną dokumentacją, co wskazywałoby, że faktura taka powinna zostać wystawiona wtedy, gdy podatnik jest w posiadaniu tejże dokumentacji. Z treści wskazanego przepisu wynika jednak, że dopuszcza się sytuacje, w których faktura korygująca in minus jest wystawiona pomimo braku stosownej dokumentacji potwierdzającej dokonanie uzgodnienia $\mathrm{z}$ nabywcą co do warunków obniżenia podstawy opodatkowania oraz dokumentacji potwierdzającej spełnienie tych warunków. W takim przypadku podatnik ma prawo do obniżenia podstawy opodatkowania/kwoty podatku należnego dopiero w rozliczeniu za okres, w którym będzie już taką dokumentację posiadał.

Taka konstrukcja przepisów nie ułatwia rozliczeń podatnika VAT. Wystawienie faktury korygującej (nawet przy ziszczeniu się okoliczności wynikających $z$ uzgodnienia) nie będzie uprawniało do obniżenia podstawy opodatkowania i kwoty podatku w razie nieposiadania przez sprzedawcę stosownej dokumentacji dotyczącej uzgodnienia i spełnienia się warunków 
(okoliczności) do pomniejszenia podstawy opodatkowania. Wówczas moment dokonania korekty przenosi się na okres, w którym niezbędne dokumenty zostaną przez podatnika zgromadzone.

\section{KOREKTA PODATKU NALICZONEGO - NOWE OBOWIĄZKI DLA NABYWCY TOWARÓW I USŁUG}

Do końca 2020 r. obowiązek nabywcy towarów lub usług pomniejszenia kwoty podatku naliczonego w związku z obniżeniem podstawy opodatkowania lub kwoty podatku należnego przez sprzedawcę był ściśle związany z otrzymaniem przez niego faktury korygującej od sprzedawcy. Były to rozwiązania jednoznaczne, a co za tym idzie - proste w stosowaniu. Wyjątek dotyczył sytuacji związanych z nieodebraniem faktury korygującej przez nabywcę i jednoczesnym posiadaniem przez niego wiedzy o zrealizowaniu transakcji zgodnie $z$ warunkami wynikającymi z korekty, co wynika z art. 86 ust. 19b ustawy VAT w brzmieniu przed dniem 1 stycznia $2021 \mathrm{r}$.

Zgodnie z nowymi zasadami (art. 86 ust. 19a ustawy VAT) w przypadku obniżenia podstawy opodatkowania lub stwierdzenia pomyłki w kwocie podatku na fakturze nabywca towarów lub usług jest zobowiązany do zmniejszenia kwoty podatku naliczonego w rozliczeniu za okres, w którym warunki do obniżenia podstawy opodatkowania dla dostawy towarów lub świadczenia usług zostały uzgodnione z dostawcą towarów (lub usługodawcą), jeśli przed upływem tego okresu warunki te zostały spełnione. Jeśli zaś warunki do obniżenia podstawy opodatkowania dla dostawy towarów (lub świadczenia usług) zostały spełnione po upływie okresu rozliczeniowego, w którym warunki te zostały uzgodnione, nabywca zobowiązany jest do pomniejszenia podatku naliczonego w rozliczeniu za okres, w którym warunki do pomniejszenia podstawy opodatkowania zostały spełnione.

Jeżeli podatnik będący nabywcą towarów lub usług nie obniżył wcześniej kwoty podatku należnego o kwotę podatku naliczonego wynikającego z faktury, której dotyczy pomniejszenie podstawy opodatkowania, a prawo do takiego obniżenia mu przysługuje, nabywca uwzględnia zmniejszenie kwoty podatku naliczonego w rozliczeniu za okres, w którym dokonuje obniżenia podatku należnego o kwotę podatku naliczonego. Rozwiązanie to wynika $\mathrm{z}$ faktu, że podatnik może obniżyć kwotę 
podatku należnego o kwotę podatku naliczonego w jednym z czterech miesięcznych okresów rozliczeniowych.

Terminu korekty podatku naliczonego przez nabywcę nie wyznacza już zatem otrzymanie faktury korygującej, ale spełnienie warunków wynikających z uzgodnienia co do obniżenia podstawy opodatkowania.

Przepis art. 86 ust. 19a ustawy o VAT może jednak budzić wątpliwości w odniesieniu do jego właściwej interpretacji. Stanowi on, że „w przypadku obniżenia podstawy opodatkowania, o którym mowa w art. 29a ust. 13", nabywca jest zobowiązany do dokonania korekty podatku naliczonego. Przepis art. 29a ust. 13 ustawy o VAT wiąże natomiast obniżenie podstawy opodatkowania przez sprzedawcę $\mathrm{z}$ wystawieniem przez niego faktury korygującej, a co więcej - z posiadaniem przez niego właściwej dokumentacji dotyczącej uzgodnienia i ziszczenia się warunków do obniżenia podstawy opodatkowania.

Powstaje zatem wątpliwość, czy nabywca powinien dokonać korekty podatku dopiero po ziszczeniu się wszystkich warunków do obniżenia przez sprzedawcę podstawy opodatkowania.

Przepis art. 86 ust. 19a ustawy VAT jest bez wątpienia wewnętrznie niespójny. Z jednej strony odnosi się do przypadków, w których obniżono podstawę opodatkowania - co zasadniczo wiąże się z wystawieniem faktury korygującej przez sprzedawcę i posiadaniem przez niego stosownej dokumentacji, a z drugiej jednocześnie wskazuje, że nabywca dokonuje korekty podatku naliczonego, co do zasady, już w rozliczeniu za okres, w którym spełnione zostaną warunki do obniżenia podstawy opodatkowania wynikające $z$ uzgodnienia.

Tymczasem okres, w którym dokonano obniżenia podstawy opodatkowania (sprzedawca wystawił fakturę korygującą i posiada stosowną dokumentację potwierdzającą uzgodnienie warunków obniżenia podstawy opodatkowania i ziszczenie się tych warunków), oraz okres, w którym ziściły się okoliczności lub warunki wynikające $\mathrm{z}$ uzgodnienia dla obniżenia podstawy opodatkowania, nie muszą być przecież tożsame. Dzieje się tak wówczas, gdy sprzedawca wystawi korektę po zakończeniu okresu rozliczeniowego, w którym ziściły się warunki do obniżenia podstawy opodatkowania wynikające $\mathrm{z}$ uzgodnienia.

Faktury korygujące powinny być, co do zasady, wystawione niezwłocznie po zaistnieniu okoliczności uzasadniających ich wystawienie. Można jednak wyobrazić sobie sytuacje, w których warunki wynikające z uzgodnienia dla dokonania obniżenia podstawy opodatkowania ziściły się ostatniego lub przedostatniego dnia miesiąca, a faktura korygująca zostanie 
wystawiona przez sprzedawcę np. pierwszego lub drugiego dnia następnego miesiąca. W takim przypadku obowiązek korekty podatku naliczonego przez nabywcę wystąpiłby wcześniej niż obniżenie podstawy opodatkowania i podatku należnego przez sprzedawcę.

Przyjęcie interpretacji, zgodnie z którą nabywca przystępuje do korekty podatku naliczonego dopiero po faktycznym obniżeniu podstawy opodatkowania przez sprzedawcę, wiązałoby się przede wszystkim z nałożeniem na nabywcę ciężarów, których spełnienie wpływa na prawidłową realizację jego ustawowych obowiązków związanych z korektą podatku naliczonego. Dokonanie korekty podatku uzależnione byłoby od posiadania przez nabywcę wiedzy co do zachowania sprzedawcy. Poza tym, czemu miałoby to służyć, skoro druga część omawianego przepisu art. 86 ust. 19a ustawy VAT wyraźnie wiąże obowiązek dokonania korekty podatku naliczonego przez nabywcę wyłącznie ze spełnieniem warunków wynikających z zawartego uzgodnienia. Wstrzymywanie się z korektą do czasu wystawienia faktury korygującej przez sprzedawcę (przy założeniu, że nabywca będzie wiedział, kiedy to nastąpi) mogłoby prowadzić jedynie do powstania zaległości i odsetek w związku z opóźnieniem w dokonaniu korekty podatku naliczonego - w sytuacji gdy faktura korygująca zostanie wystawiona w okresie innym niż spełnienie warunków wynikających z uzgodnienia.

Odwołanie się w przepisie art. 86 ust. 19a ustawy VAT do przypadku obniżenia podstawy opodatkowania, a zatem przypadku, w którym nastąpiło obniżenie podstawy opodatkowania, może wskazywać na próbę zachowania korelacji pomiędzy terminem dokonania obniżenia podstawy opodatkowania przez sprzedawcę a terminem, w którym nabywca musi skorygować podatek naliczony. Korelacja taka jednak nie wystąpi, gdy termin wystawienia faktury korygującej i zgromadzenia stosownej dokumentacji przez sprzedawcę nie ma miejsca w okresie, w którym ziściły się warunki wynikające $\mathrm{z}$ samego uzgodnienia.

Pomimo pewnej niespójności omawianych przepisów to wszakże moment spełnienia warunków do obniżenia podstawy opodatkowania (wynikających z zawartego uzgodnienia) wyznacza moment do dokonania przez nabywcę korekty podatku naliczonego.

Wskazują na to również „Przykłady stosowania nowych zasad rozliczania faktur korygujących in minus wraz z omówieniem” zawarte w Objaśnieniach podatkowych dotyczących Slim VAT. W przykładach tych wiąże się moment powstania obowiązku dokonania korekty podatku naliczonego ze ziszczeniem się warunków do obniżenia podstawy opodatkowania 
wynikających z uzgodnienia, a nie ze spełnienia przez sprzedawcę wszystkich warunków do faktycznego obniżenia podstawy.

Znamienne jest jednak to, że we wszystkich przykładach podanych w Objaśnieniach podatkowych dotyczących Slim VAT sprzedawca wystawił fakturę korygującą dokładnie w miesiącu, w którym ziściły się warunki wynikające z uzgodnienia.

Uwzględniając powyższe, „oderwanie” obowiązku dokonania korekty podatku naliczonego przez nabywcę od otrzymania faktury korygującej od sprzedawcy nie stanowi dla nabywcy uproszczenia w dokonaniu prawidłowej korekty podatku naliczonego. Wiąże się też z ryzykiem nieprawidłowego rozpoznania momentu dokonania korekty podatku naliczonego. Ponadto może się wiązać z koniecznością pomniejszenia przez nabywcę podatku naliczonego, podczas gdy podstawa opodatkowania (wynagrodzenie) w danym okresie (lub w ogóle) nie została przez sprzedawcę obniżona. Sytuacja może okazać się bardziej skomplikowana, gdy pomiędzy stronami transakcji wystąpi spór co do ziszczenia się przesłanek (warunków) obniżenia podstawy opodatkowania i sprzedawca nie będzie wystawiał korekty faktury co do zasady. Przepisy są niespójne, a przez to rodzą wątpliwości w zakresie ich prawidłowej interpretacji i zastosowania.

\section{Podsumowanie}

Nowe rozwiązania dotyczące zasad pomniejszania podstawy opodatkowania i wystawiania faktur korygujących in minus wprawdzie zmieniły w sposób istotny obowiązki obu stron transakcji podlegających opodatkowaniu podatkiem VAT, to jednak nie przyczyniły się znacząco (lub w ogóle) do uproszczenia rozliczenia tego podatku przez podatników w związku z korektą. Pewne uproszczenie dotyczy jedynie sprzedawcy, który może dokonać korekty podstawy opodatkowania i kwoty podatku bez potwierdzenia otrzymania faktury korygującej przez nabywcę. Pozytywny efekt zmian w tym zakresie dla sprzedawcy został jednak nieco zniwelowany w wyniku wprowadzenia innych warunków do dokonania korekty (zawieranie uzgodnień w zakresie obniżenia podstawy opodatkowania $\mathrm{z}$ nabywcą, gromadzenie stosownej dokumentacji potwierdzającej zawarte uzgodnienie oraz spełnienie warunków do dokonania korekty). Nowe przepisy niosą też wiele wątpliwości interpretacyjnych odnośnie do momentu wystawienia faktury korygującej.

Ciężar i ryzyko podatkowe związane z korektami podstawy opodatkowania VAT i kwoty podatku należnego in minus zdecydowanie zostały 
przesunięte w kierunku nabywcy. „Oderwanie” korekty podatku naliczonego przez nabywcę od otrzymania faktury korygującej wymusza bieżące śledzenie wszystkich zapisów umów związanych $\mathrm{z}$ ewentualnym obniżeniem podstawy opodatkowania, uzgodnień i okoliczności oraz terminów związanych $\mathrm{z}$ realizacją tych umów i uzgodnień. Niesie to za sobą pewne ryzyko właściwego rozpoznania momentu, w którym należy dokonać korekty podatku naliczonego - zwłaszcza przy sporze pomiędzy podatnikami co do ziszczenia się warunków do obniżenia podstawy opodatkowania.

Nowe rozwiązania dotyczące warunków dokonania korekty podstawy opodatkowania lub podatku należnego u sprzedawcy (in minus) nie są $\mathrm{w}$ pełni skorelowane $\mathrm{z}$ rozwiązaniami w zakresie obowiązku pomniejszenia podatku naliczonego przez nabywcę. Może to prowadzić do sytuacji, w których korekta podatku naliczonego przez nabywcę powinna zostać dokonana w okresie wcześniejszym niż zmniejszenie podstawy opodatkowania i kwoty podatku należnego przez sprzedawcę. Niewątpliwie prowadzi to do nadmiernego obciążenia nabywcy ciężarem podatku VAT i rodzi wątpliwości dotyczące zachowania neutralności tego podatku.

Wprowadzone rozwiązania są ponadto niespójne, co przekłada się na pewne wątpliwości w zakresie ich prawidłowej interpretacji.

\section{BIBLIOGRAFIA}

Matarewicz J., Najważniejsze zmiany $w$ ramach pakietu Slim VAT - próba oceny zaproponowanych rozwiązań, LEX/el. 2020.

Rogowska-Rajda B., Tratkiewicz T., Prawo do odliczania VAT w świetle orzecznictwa TSUE, Warszawa 2018.

\section{NEW REGULATIONS ON IN MINUS CORRECTION INVOICES \\ - SIMPLIFICATION OF VAT SETTLEMENT FOR TAXPAYERS?}

Summary. The main thesis of the article is that the changes introduced as of January 1, 2021 in the act on tax on goods and services in terms of lowering the tax base and issuing corrective invoices in minus, contrary to the adopted assumptions, do not simplify the settlement of tax on goods and services - especially on the side of the buyer of goods and services.

The imprecision of some regulations may lead to a disturbance of legal certainty and its consistent interpretation. The new solutions may also lead to a disturbance of the symmetry of the tax burden on both parties to the transaction - the deadline for making the tax base adjustment by the seller is not correlated with the obligation to correct the tax charged by the buyer.

Keywords: value added tax, VAT invoice, corrective invoice in minus, tax deduction 